\title{
PERIODATE-OXIDIZED ALGINATE AS POLYCONDENSATION REAGENT FOR HEMOGLOBIN
}

\author{
FLORINA SCURTU ${ }^{a}$, ANAMARIA POPA ${ }^{a}$, \\ RADU SILAGHI-DUMITRESCU ${ }^{a *}$
}

\begin{abstract}
We have previously demonstrated that derivatization of hemoglobin with periodate-modified sugar derivatives incurs increases in the pro-oxidant reactivity and, also, that serum bovine serum albumin can resolve this problem entirely. Here, we described a new polymer based on hemoglobin and another oxygen-containing compound, alginate. The rate of autooxidation increases after derivatization, but serum albumin alleviates this problem. The peroxide reactivity and oxygen affinity were also tested but no significant differences were observed between derivatized and native hemoglobin.
\end{abstract}

Keywords: blood substitute, hemoglobin, alginate, oxidative stress

\section{INTRODUCTION}

It was demonstrated that acellular hemoglobin, even when carefully purified, does not represent by itself a solution for hemoglobin-based oxygen carriers (HBOC) because of negative side-effects:[1-3] the first key problem with free hemoglobin is it slow molecular volume, leading to extravasation and indirectly other to problems(high oxygen affinity, vasoactive properties, renal toxicity). $[4,5]$ The challenge in creating a reasonable blood substitute is to increase their molecular weight by chemical and/or genetic modification.[6-8] On the other hand, modification of the protein structure can affect other properties, including autooxidation rates, oxygen affinity, cooperativity, affinity for nitrosative and/or oxidative stress agents, and other functions of hemoglobin such as $\mathrm{NO}$ and $\mathrm{CO}_{2}$ transport.[9]

\footnotetext{
a Babes-Bolyai University, Faculty of Chemistry and Chemical Engineering, 11 Arany Janos str. RO-400028, Cluj-Napoca, Romania

*Corresponding author; email: rsilaghi@chem.ubbcluj.ro
} 
Intermolecularly-crosslinked hemoglobins produced using polyaldehydes have been used extensively to modify the negative properties of native $\mathrm{Hb}$. The most common reagents in this respect are glutaraldehyde, formaldehyde, acetaldehyde; $[10,11]$ however, a variety of dialdehydes can also be obtained via oxidation by sodium periodate of diverse water-soluble sugar derivatives (dextran, ATP, starch), or even compounds like polyethylene glycol.[12,13] Here, for the first time, we report that sodium alginate can also be used for crosslinking hemoglobin. Parameters like molecular size, autooxidation rate and oxygen affinity appears to be affected after the polymerization process. The process may in principle be applicable to crosslinking of other materials as well.

\section{RESULTS ANS DISCUSSION}

Oxidation of alginate with sodium periodate was performed in order to ring-open the 1,2-diols to yield dialdehydes (Figure 1) which can then be employed for polycondensation of proteins, namely hemoglobin and albumin. Figure 2 shows an SDS-PAGE gel and gel-filtration chromatograms illustrating that oxidized alginate indeed induces an increase in molecular weight. Introduction of BSA in the reaction mixture leads to lower molecular weights for copolymers comparative to the polymers as illustrated in Table 1.
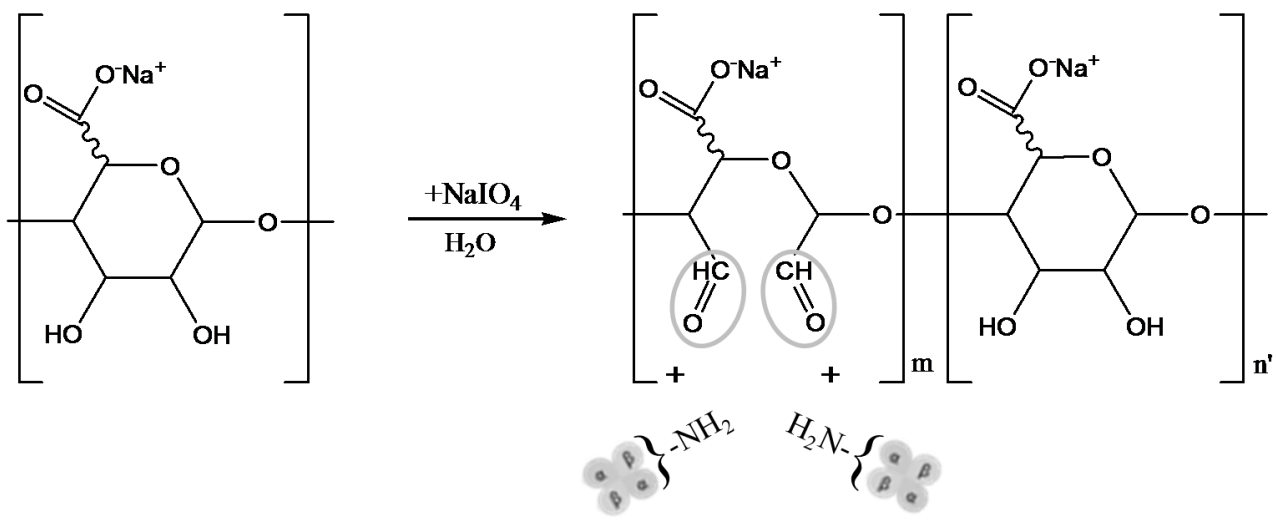

Figure 1. Oxidation of sodium alginate by periodate 
A

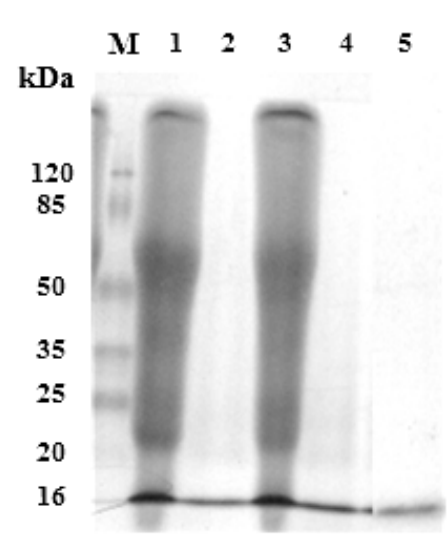

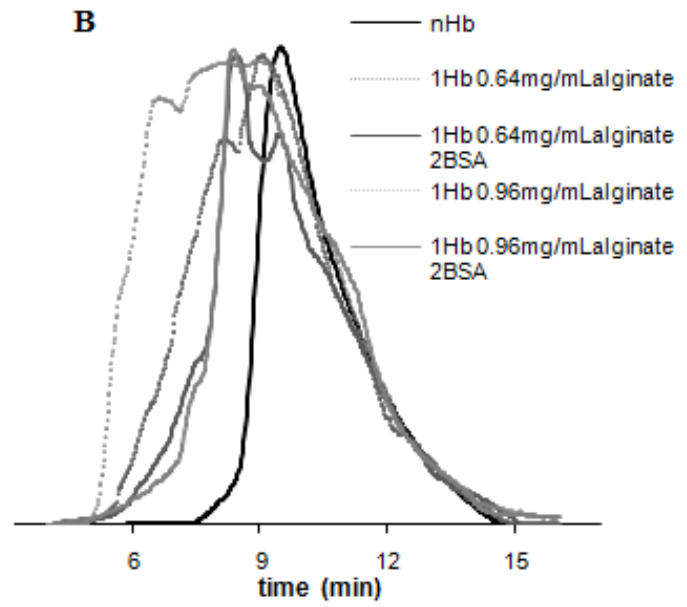

Figure2.A) SDS-PAGE illustrating the influence of alginate concentration upon polymerization degree. 1- $1 \mathrm{mM} \mathrm{Hb}+0.96 \mathrm{mg} / \mathrm{mL}$ alginate $+2 \mathrm{mM} \mathrm{BSA}$,

2- $1 \mathrm{mM} \mathrm{Hb}+0.96 \mathrm{mg} / \mathrm{mL}$ alginate, $3-1 \mathrm{mM} \mathrm{Hb}+0.64 \mathrm{mg} / \mathrm{mL}$ alginate $+2 \mathrm{mM} \mathrm{BSA}$,

4- $1 \mathrm{mM} \mathrm{Hb}+0.64 \mathrm{mg} / \mathrm{mL}$ alginate, 5- native $\mathrm{Hb}$. B)Size-exclusion chromatograms for $\mathrm{Hb}$ derivatized with different concentration of alginate.

Conditions: $20 \mathrm{mM}$ Tris $\mathrm{pH} 7.4,150 \mathrm{mM} \mathrm{NaCl}$, room temperature

Table 1 also shows the autooxidation rate values. While oxidized alginate induces drastic autooxidation, bovine serum albumin can alleviate this problem. Thus, the amount of metHb formed is two times lower if in the reaction mixture is added $B S A$.

Table 1. Molecular weight and autooxidation rates (express in percentage of metHb formed) values.

\begin{tabular}{lcc}
\hline & $\begin{array}{c}\text { Molecular } \\
\text { weight } \\
\text { [kDa] }\end{array}$ & $\begin{array}{c}\text { Autooxidation } \\
\text { rate(\%) }\end{array}$ \\
\hline native $\mathrm{Hb}$ & 64 & 14.29 \\
$1 \mathrm{Hb}+0.64 \mathrm{mg} / \mathrm{mL}$ alginate & $210-77$ & 30.81 \\
$1 \mathrm{Hb}+0.64 \mathrm{mg} / \mathrm{mL}$ alginate $+2 \mathrm{BSA}$ & $230-64$ & 18.22 \\
$1 \mathrm{Hb}+0.96 \mathrm{mg} / \mathrm{mL}$ alginate & $>500(850)-80$ & 44.82 \\
$1 \mathrm{Hb}+0.96 \mathrm{mg} / \mathrm{mL}$ alginate $+2 \mathrm{BSA}$ & $170-64$ & 22.03 \\
\hline
\end{tabular}


Figure 3 illustrates the time course at $425 \mathrm{~nm}$ during the reaction of hydrogen peroxide with poly- and copolymerized $\mathrm{Hb}$. This wavelength is characteristic of ferryl form (FelV - so called Compound II). [7,14,15] There is no significant difference between the derivatized $\mathrm{Hb}$ and the native: both the yield of ferryl form and its stability is similar with to that of native $\mathrm{Hb}$.

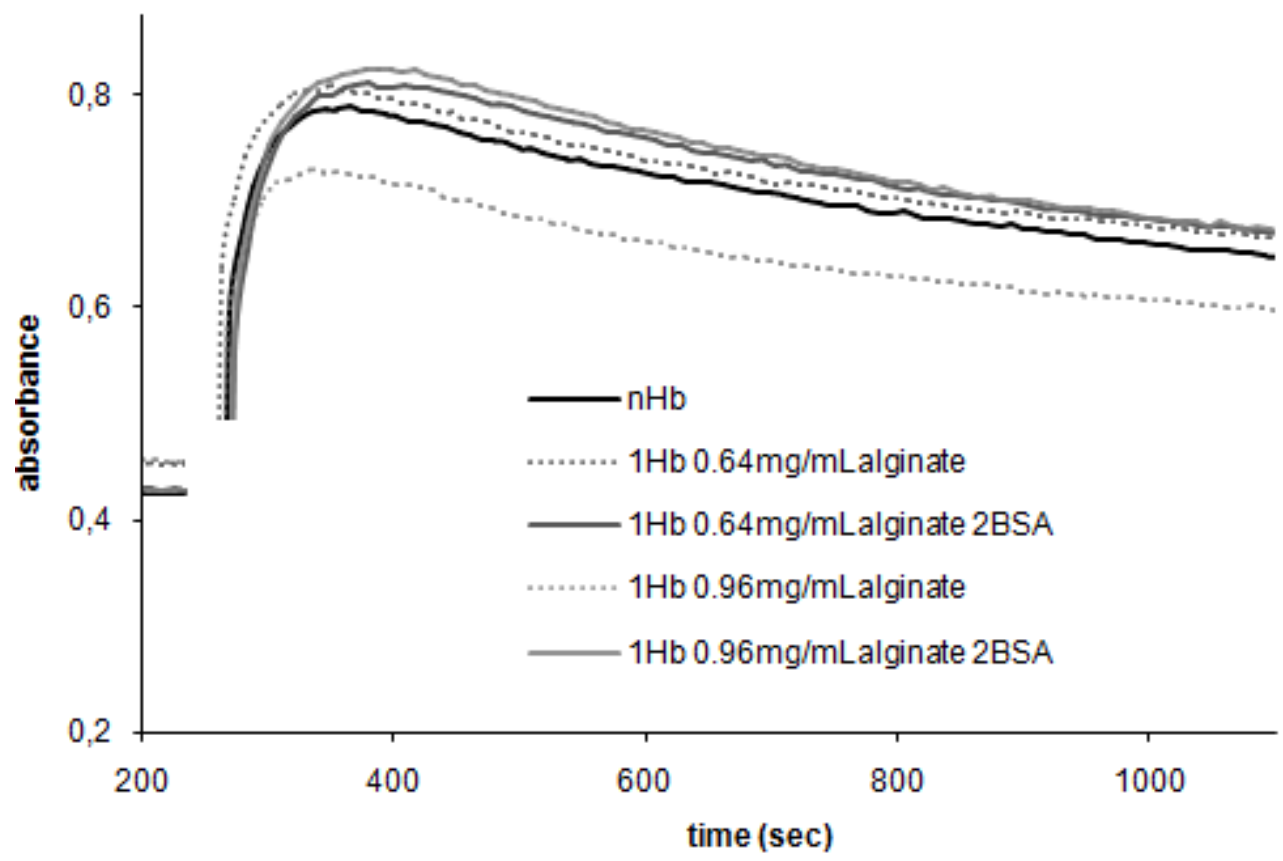

Figure 3. Time course for the reaction of ferric native $\mathrm{Hb}$, poly- and copolymerized $\mathrm{Hb}$ with hydrogen peroxide. Conditions: $10 \mu \mathrm{M}$ protein, $80 \mu \mathrm{M}$ peroxide, PBS, room temperature

Figure 4 illustrates oxygen binding curves for copolymerized and native hemoglobin. It may be seen that the cooperativity effect disappears in derivatized $\mathrm{Hb}$ while affinity towards oxygen increases compared with native hemoglobin, in line with observations previously noted for most other polycondensates based on hemoglobin or other related proteins.[10,16-22] 


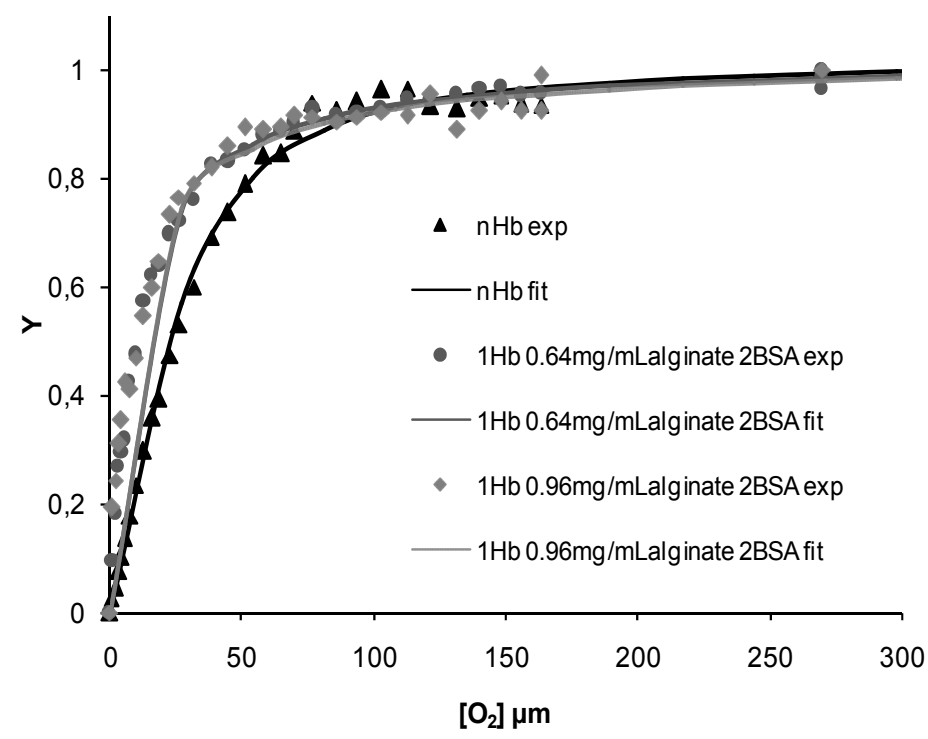

Figure 4. Oxygen saturation curves of native $\mathrm{Hb}$ and polymerized $\mathrm{Hb}$.

Conditions: PBS, room temperature

Table 2. $K_{d}$ values and Hill coefficients ( $n$ ) for poly- and copolymers.

\begin{tabular}{lrr}
\hline & $\mathbf{K}_{\mathbf{d}}$ & $\mathbf{n}$ \\
\hline native $\mathrm{Hb}$ & 22.99 & 1.55 \\
$1 \mathrm{Hb}+0.64 \mathrm{mg} / \mathrm{mL}$ alginate $+2 \mathrm{BSA}$ & 10.46 & 1.04 \\
$1 \mathrm{Hb}+0.96 \mathrm{mg} / \mathrm{mL}$ alginate $+2 \mathrm{BSA}$ & 9.11 & 0.92 \\
\hline
\end{tabular}

\section{CONCLUSIONS}

The derivatization procedure described here show that polymerization of hemoglobin with oxidized alginate lead to an increase in autooxidation rate, but addition of bovine serum albumin alleviates this problem. Also, molecular size and oxygen affinity was higher in poly $\mathrm{Hb}$ than in nativeHb. By analogy with other periodate-derived hemoglobin polymers,[13] one should expect this lack of reactivity to be paralleled by improved performance on cellular cultures if using such polycondensates as (semi)-artificial carriers for molecular oxygen. On the other hand, the protocol described here can be viewed as generally applicable for protein derivatization/conjugation. 


\section{EXPERIMENTAL SECTION}

Bovine hemoglobin was purified from bovine blood following a general protocol of Antonini and Brunori.[23] The blood, freshly drawn on citrate, was centrifugated 15 minutes at $5000 \mathrm{rpm}$ to separate the red blood cells, which were then washed three times with $5 \mathrm{mM}$ phosphate $\mathrm{pH} 7.4+150 \mathrm{mM} \mathrm{NaCl}$. Hemoglobin was manipulated in phosphate buffer saline (PBS) unless otherwise mentioned and concentration in text are given per heme rather than per tetramer. The met form of the hemoglobin were prepared by ferricyanide treatment as previously described.[24-26] Bovine serum albumin (BSA, fraction V, from Sigma-Aldrich, Germany) was used as provided without further purification.

For alginate oxidation $0.01 \mathrm{~g} / \mathrm{mL}$ solution were prepared in $18.1 \mathrm{M} \Omega$ deionized water. The solution was oxidized with sodium periodate $\left(\mathrm{NalO}_{4}\right.$, Merck) $(0.1 \mathrm{~g} / \mathrm{mL})$ for 1 hour at room temperature in order to ring-open the 1,2-diols to yield dialdehydes (Figure 1). For polymerization of $\mathrm{Hb}$ with alginate, $1 \mathrm{mM} \mathrm{Hb}$ was reacted with $0.64 \mathrm{mg} / \mathrm{mL}$ or $0.96 \mathrm{mg} / \mathrm{mL}$ alginate oxidized. The reaction was performed under stirring at $4^{\circ} \mathrm{C}$. The reaction was stopped by addition of $\mathrm{NaBH}_{4}$, which reduces imine bonds to stable amines and also quenches excess carbonyl groups. The product was dialyzed in $50 \mathrm{mM}$ Tris buffer with $150 \mathrm{mMNaCl}, 7.4$ to remove excess $\mathrm{NaBH}_{4}$ and side-products. The resulting protein solutions were subsequently analyzed by $15 \%$ SDS-PAGE and by analytical size exclusion chromatography on a Superdex $2005 / 150 \mathrm{GL}$ column (GE Healthcare, Sweden), $0.25 \mathrm{~mL} / \mathrm{min}$ flow rate with a mobile phase of $20 \mathrm{mM}$ Tris pH 7.4 buffer with $150 \mathrm{mM} \mathrm{NaCl}$. The absorbance was monitored at $280 \mathrm{~nm}$. Molecular weights were determined based on a calibration curve employing a molecular weight standard kit (Sigma-Aldrich) containing carbonic anhydrase (29 kDa), bovine serum albumin (BSA, $66 \mathrm{kDa})$, alcohol dehydrogenase (150 kDa), amylase (200 kDa), apoferritin (443 kDa), thyroglobulin (669 kDa) and blue dextran (void volume marker).

Autooxidation experiments were performed by incubation of oxy- $\mathrm{Hb}$ (native or polymerized) at $37^{\circ} \mathrm{C}$ in an incubator and measuring UV-vis spectra of the $\mathrm{Hb}$ before and after incubation times of up to 4 hours. The change in absorbance at $630 \mathrm{~nm}$ was used to determine the rate of autooxidation. UV-vis spectra were recorded on Agilent 8453 (Agilent, Inc.) and Cary 50 (Varian, Inc) instruments Cary 50 (Varian, Inc) instruments.

Dioxygen affinity and autooxidation measurements were in PBS 7.4 at room temperature. 


\section{REFERENCES}

1. H. Bunn, J.H. Jandl, Journal of Experimental Medicine, 1969, 129, 925

2. X. Liu, M. J.S. Miller, M.S. Joshi, H. Sadowska-Krowicka, D.A. Clark, J.R. Lancaster, Journal of Biological Chemistry, 1998, 273, 18709

3. J.R. Hess, R.F. Reiss, Translational Medicine Reviews, 1996, 10, 276

4. A.I. Alayash, Nature Reviews in Drug Discovery, 2004, 3, 152

5. D.H. Doherty, M.P. Doyle, S.R. Curry, R.J. Vali, T.J. Fattor, J.S. Olson, D.D. Lemon, Nature Biotechnology, 1998, 16, 672

6. R.M. Winslow, Artificial Organs, 2004, 28, 800

7. B.J. Reeder, M. Grey, R.L. Silaghi-Dumitrescu, D.A. Svistunenko, L. Bulow, C.E. Cooper, M.T. Wilson, Journal of Biological Chemistry, 2008, 283, 30780

8. I. Portoro, L. Kocsis, P. Herman, D. Caccia, M. Perrella, L. Ronda, S. Bruno, S. Bettati, C. Micalella, A. Mozzarelli, A. Varga, M. Vas, K.C. Lowe, A. Eke, Biochimica Biophysica Acta, 2008, 1784, 1402

9. J.G. Riess, Chemical Reviews, 2001, 101, 2797

10. F. Deac, A. Todea, R. Silaghi-Dumitrescu Glutaraldehyde derivatization of hemoglobin: a potential blood substitute; Silaghi-Dumitrescu, R. and Garban, G., Ed.; Cluj University Press: Cluj-Napoca, Romania, 2009, pp 165

11. S.G.R.C., H.H.D., Journal of Biological Chemistry, 1986, 261, 6811

12. J.H. Eike, A.F. Palmer, Biotechnology Progress, 2004, 20, 953

13. F. Deac, B. lacob, E. Fischer-Fodor, G. Damian, R. Silaghi-Dumitrescu, Journal of Biochemistry, 2011, 149, 75

14. B.J. Reeder, D.A. Svistunenko, C.E. Cooper, M.T. Wilson, Antioxidants\& Redox Signaling, 2004, 6, 954

15. R. Silaghi-Dumitrescu, B.J. Reeder, P. Nicholls, C.E. Cooper, M.T. Wilson, Biochemical Journal, 2007, 403, 391

16. A.C. Mot, A. Roman, I. Lupan, D.M. Kurtz, R. Silaghi-Dumitrescu, Protein Journal, 2010, 29, 387

17. M. Arkosi, F. Scurtu, A. Vulpoi, R. Silaghi-Dumitrescu, D.M. Kurtz, Jr., Artificial Cells and Blood Substitutes, 2016, 45, 218

18. D. Hathazi, A.C. Mot, A. Vaida, F. Scurtu, I. Lupan, E. Fischer-Fodor, G. Damian, D.M. Kurtz, Jr., R. Silaghi-Dumitrescu, Biomacromolecules, 2014, 15,1920

19. F. Scurtu, O. Zolog, B. lacob, R. Silaghi-Dumitrescu, Artificial Cells, Nanomedicine and Biotechnology, 2014, 42, 13

20. V.F. Scurtu, A.C. Mot, R. Silaghi-Dumitrescu, Pharmaceuticals, 2013, 6, 867

21. F. Deac, B. lacob, E. Fischer-Fodor, G. Damian, R. Silaghi-Dumitrescu, Journal of Biochemistry, 2011, 149, 75

22. O. Zolog, A. Mot, F. Deac, A. Roman, E. Fischer-Fodor, R. SilaghiDumitrescu, Protein Journal, 2011, 30, 27

23. E. Antonini, M. Brunori, Hemoglobin and Myoglobin in their Reaction with Ligands; North-Holland: Amsterdam, 1971 
24. B.J. Reeder, D.A. Svistunenko, M.A. Sharpe, M.T. Wilson, Biochemistry, 2002, 41, 367

25. J. Dunne, D.A. Svistunenko, A.I. Alayash, M.T. Wilson, C.E. Cooper, Advances in Experimental Medicine and Biology, 1999, 471, 9

26. J. Dunne, A. Caron, P. Menu, A.I. Alayash, P.W. Buehler, M.T. Wilson, R. Silaghi-Dumitrescu, B. Faivre, C.E. Cooper, Biochemical Journal, 2006, 399, 513 